\title{
Örgütsel Sessizlik ve Boyutları Üzerine Nitel Bir Araştırma
}

\section{İlknur ÖZTÜRK ${ }^{1}$}

ÖZ: Örgütsel sessizlik, işgörenlerin farkl nedenlere bağlı olarak, fikirlerini ve görüşlerini ifade etmekten çekinerek sessiz kalmayı tercih ettikleri durumu ifade etmektedir. Çalışmanın amacı, örgütsel sessizlik ve literatürde yer alan sessizlik boyutlarına (kabullenici, korunmacı ve koruma amaçll) göre çalışanların bunu nasıl deneyimlediğini ve anlamlandırdiğııı incelemeye çallşmaktır. Bu çalışmanin örneklemini, bir eğitim kurumunda çalı̧̧an 3 ve 10 yıl iş deneyimine sahip 10 kadın oluşturmaktadır. Görüşme birebir yapılarak örgütsel sessizlik ile ilgili deneyimlerini anlatmaları istenmiştir. Örgütsel sessizlik boyutlarına ait kodlama temaları verdikleri cevaplardan çıkarılmıştır. Çalışmada elde edilen veriler, tematik içerik analizi yöntemini kullanarak çözümlenmiştir. Tematik analiz sürecinde; verilerin kodlanması, temaların oluşturulmasl, temaların düzenlenmesi, bulguların tanımlanması ve yorumlanması aşamaları izlenmiştir. Yapılan görü̧smeler sonucunda; çalışanların kabullenici, korunmacı ve koruma amaçlı sessizlik türlerine uygun ifadelere yer verdiği görülmüştür. Ayrıca, örgütsel sessizliği yordayan faktörlerden, örgütsel adalet, örgütsel bağlllık ve mobbing gibi faktörlerinden kaynaklı sessizliği tercih ettiklerini göstermiştir.

Anahtar Kelimeler: Örgütsel Sessizlik, Örgütsel Adalet, Örgütsel Bağlllık, Nitel Araştırma

\section{A Qualitative Research on Organizational Silence and Its Dimensions}

\begin{abstract}
Organizational silence refers to the situation in which employees prefer to remain silent for different reasons, avoiding expressing their ideas and opinions. The aim of the study is to examine how the employees experience and make sense of it according to the dimensions of organizational silence and silence dimensions in the literature (accepting, protectionist and protective purposes). The sample of this study consists of 10 women with 3 and 10 years of work experience working in an educational institution. The interviews were conducted one to one to explain their experiences about organizational silence. Coding themes of organizational silence dimensions were obtained from their answers. The data obtained in the study were analyzed using thematic content analysis method. In the process of thematic analysis: the steps of coding the data, creating themes, arranging themes, defining and interpreting the findings were followed. As a result of the interviews, it was seen that the employees included expressions suitable for the types of silence for accepting, protective and protective purposes. In addition, they preferred silence due to factors such as organizational justice, organizational commitment and mobbing.
\end{abstract}

Keywords: Organizational Silence, Organizational Justice, Organizational Commitment, Qualitative Research

${ }^{1}$ Dr. Öğr. Üyesi, Çağ Üniversitesi, İktisadi ve İdari Bilimler Fakültesi, ilknurozturk@cag.edu.tr, orcid.org/0000-0002-2079-0383 


\section{Giriş}

İşletmelerin, günümüzde daha iyi rekabet etmek adına çalışanlarından müşteri beklentilerini karşılamak, kaliteye odaklanmak, fikir vermek ve sorumluluk almak gibi beklentileri vardır. Bu beklentileri karşılamak için, bilgi paylaşımı yapmaktan korkmayan ve görüşlerini açıkça ifade eden çalışanlara ihtiyaç duyulmaktadır.

İşletmelerin başarısı için kritik öneme sahip olan çalışanlar; değişimin, yaratıcılığın, öğrenme ve yeniliklerin temel dinamikleridir. Küreselleşen dünyada, işletmeler fikirlerini açıkça ifade eden çalışanlara ihtiyaç duymakta: aynı şekilde, çalışanlar da kendilerini rahatlıkla ifade edebilecekleri işletmeleri tercih etmektedir. Hem çalışanların hem de işletmelerin yüksek motivasyona sahip olması sessizliğin ortadan kalkmasıyla mümkün olmaktadır (Liu, Wu ve Ma, 2009). Sessizlik kavramsal olarak içinde farklı duygu, düşünce ve dinamikleri barındıran anlaşılması güç karmaşık bir süreci barındırmaktadır. Bu özelliğinden dolayı çalışanların sessiz kalma nedenlerinin doğru bir şekilde anlaşılması işletme için önem arz etmektedir (Üçok ve Torun, 2015). Örgütsel sessizlik; işgörenlerin, yönetsel ve fonksiyonel konularda kasitlı olarak fikir sunmaması (Premeaux ve Bedeian, 2003:1537), endişelerini dile getirmede kararsız kalan çalışanın korkuya dayalı olarak sessiz kalması (Milliken ve Morrison, 2003:1563), çalışanların kasıtlı olarak görüş ve fikirlerini dile getirmek istememesi ( Scott, 1993) olarak tanımlanmaktadır. $\mathrm{Bu}$ çalışmanın amacı, örgütlerde varolan fakat farkına varılmadığında yıkıcı sonuçlar ortaya çıkaran örgütsel sessizlik ve boyutlarını nitel bir çalışmayla incelemeye çalışmaktır. Bu çalışma için kullanılacak yöntem; nitel araştırmanın ilgi odağı olan bireylerin olayları nasıl yaşadığı ve anlamlandırdığını belirlemeye çalışan tematik içerik analizidir. Bu çalışma, örgütsel sessizlik kavramı ve boyutlarına (kabullenici, korunmacı ve koruma amaçlı) değinerek, çalışanların bunu nasıl deneyimleyip anlamlandırdığını belirlemek amacıyla nitel olarak gerçekleştirilmiştir. Örgütsel sessizlikle ilgili çalışmaların literatürde az çalışıldığ 1 dikkate alındığında, bu çalışmanın katkı sağlayacağı düşünülmektedir.

\section{2. Örgütsel Sessizlik ve Boyutları}

Örgütsel sessizlik, işletmelerde yaygın bir durum olmasına karşın literatürde kendine yeteri kadar yer bulamamasindan dolayı yeni bir kavram olarak değerlendirilebilmektedir (Durak, 2014: 89). İşletmelerde çalışanların sessiz kalmayı tercih etmelerinin teorik temelleri, bekleyiş teorisi, sessizlik sarmalı, susma etkisi, kendini uyarlama teorisi ve fayda-maliyet analizine dayanmaktadır (Premeaux, 2001:9; Uçar, 2016:71; Çakıc1, 2007:152-153; Acaray, 2014:97).

Sessizlik kavramı tarihsel açıdan üç dönemi (dalgayı) kapsamaktadır. 1970'lerden 1980'lerin ortasına kadar olan süreç ilk dalga, 1980'lerin ortasından 2000'lere kadar ikinci dalga ve 2000'den günümüze üçüncü dalga olarak incelenmiştir (Brindsfield, Edwards ve Greenberg 2009, akt. Şevik, 2019). Üç dönem incelendiğinde ilk dalganın iletişim bilimi üzerine, ikinci dalganın ses/sessizlik 
kavramının yönetim ile ilişkisi üzerine ve üçüncü dalganın ise, örgütsel sessizlik üzerine yoğunlaştığı görülmekledir (Acaray, 2014: 96).

Örgütsel sessizlik, işgörenlerin yönetsel veya fonksiyonel görevlerde meydana gelen sorunlarla ilgili bilinçli olarak fikir sunmaması durumudur. Yönetim araştırmacıları, iş yeri uygulamaları için, insan faktörünün önemli bir girdi oluşturduğunu savunurken, birçok işgörenin görüşlerini ifade etmediklerini ve işle ilgili konularda sessiz kaldıklarını belirtmektedirler (Premeaux ve Bedeian, 2003:1537). Örgütlerdeki bireyler, işle ilgili endişelerini dile getirme veya getirmeme konusunda kararsız kalmakta ve bunu, sorunu çözmek istemeyen yöneticilerinin hiyerarşi bağlamında kendilerini cezalandırılabileceği korkusuyla yapmaktadırlar (Milliken ve Morrison, 2003:1563).

İşgörenler; açık kapı politikaları, öneri veya şikâyet sistemleri, toplantılar, yüz yüze iletişim vb. yolları üstlerine ulaşma yolları olarak görmektedirler. Fakat işgörenler sessiz kalmayı tercih edip, bunu da birlikte hareket etmek suretiyle yaparsa, örgütler bu durumdan olumsuz etkilenebilmektedir (Çakıc1, 2010:3). Çakıcı (2008), en çok konuşması gereken kurumun üniversiteler olacağı düşüncesiyle üniversitelerdeki akademik kadroyla, örgütsel sessizlik üzerine bir araştırma yapmıştır. Araştırma sonucuna göre; üniversite personelinin \%30'u konuşmayı tercih ederken \%70'i sessiz kalmayı tercih etmiştir. Akademik personelin özellikle, etik konular, çalışan performansı, çalışma olanakları, yönetim sorunu ve kurumu iyileştirme konularında sessiz kaldıklarını ortaya koymuştur.

Örgütlerde sessizlik kavramı farklı şekillerde ortaya çıkmaktadır. Ortaya çıkan bu sessizlik durumu; bazen konu ile ilgili bilgi eksikliği, bazen başkalarının fikirlerine uyma, bazen kendini koruma ya da örgütü koruma, bazen karar vermeden kaçınma vb. nedenlerden kaynaklanabilmektedir (Acaray, 2014:132). Burada önemli olan çalışanın sessizliğinin farkına varılması ve nedeninin araştırılarak önlem alınmasidir.

Örgütsel sessizlik boyutlar açısından incelendiğinde; Pinder ve Harlos (2001) sessizliğin iki boyutu olduğunu ifade etmiştir. Van Dyne, Ang ve Botero (2003) ise Pinder ve Harlosun çalışmasından yararlanarak sessizliğin üç boyutu olduğundan bahsetmişlerdir. Sınıflama; kabullenici, korunma amaçlı ve koruma amaçlı sessizlik şeklindedir. Bunlar sessizliğin; 3K'sı olarak değerlendirilebilmektedir (Çakıcı, 2010; 31-32).

Kabullenici Sessizlik; çalışanların olaylar veya sorunlar karşısında ortaya çıkan durumlara rıza göstermesi ve herhangi bir fikir beyan etmemesi olarak tanımlanmaktadır. Çalışanın bilinçli olarak sessiz kalmayı istemesi ve kendisini olayların dışında tutma eğiliminde olmasıdır. Çalışanlar, örgütsel koşulları olduğu gibi kabul ederek koşulları değiştirme eğilimi içerisinde bulunmamaktadırlar. (Pinder ve Harlos, 2001:348)

Korunmacı Sessizlik; çalışanlar içgüdüsel olarak kendini koruma davranışı eğiliminde bulunmaktadırlar. Çalışanların dışarıdan gelebilecek tehlike ve 
tepkilerden korkmasından kaynaklı bilgi, fikir ve görüşlerini saklaması olarak tanımlanmaktadır (Dyne vd., 2003:1367). Pinder ve Harlos (2001), korunmacı sessizliği, çalışanların, var olan durumu değiştirebilecek fikir ve görüşlere sahip olmasına rağmen bunu ifade etmekte isteksiz davrandıkları şeklinde tanımlamaktadırlar.

Koruma Amaçlı Sessizlik; çalışanlar, diğer bireylerin ve örgütün menfaatini düşünerek, örgüte veya bireye fayda sağlamak amacıyla herhangi bir durum karşısında bilgi ve fikir sessizliğinin aksine, düşüncelerin açıkça ifade edilmesinin olumsuz sonuçlarından korkmaktan ziyade diğer bireylerin ve örgütün iyiliği adına sessiz kalmayı tercih etmektedirler (Çakıc1, 2010: 34).

Yapılan tanımlardan da anlaşıldığı üzere, sessizlik çalışanların daha çok bilinçli olarak sessiz kaldığını ve düşüncelerini açıkça ifade etmediklerini göstermektedir. Burada önemli çalışanın herhangi bir olayla ilgili sessiz kalmayı kasıtlı olarak yapıp yapmadığını doğru bir şekilde anlamak gerekmektedir.

\section{3. Örgütsel Sessizlik İle İlgili Yapılan Çalıșmalar}

Detert ve Edmondson (2005), çok uluslu bir şirketin 193 çalışanıyla yaptığı araştırmada, yetki sahiplerinin fikirlerine verecekleri olumsuz tepkilerin altını çizen çalışanlar, yardım edebilecekleri konularda dahi sessiz kalmayı tercih ettiklerini ifade etmişlerdir. Milliken, Morrison ve Hewlin (2003) tarafından 40 çalışanla yapılan araştırmada, çalışanların genelde, olumsuz olarak görülerek etiketlenme korkusu yaşadığını ve bu korkunun ilişkilere zarar vereceği endişesi taşıdığını dolayısıyla sessiz kalmayı tercih ettikleri ifade edilmektedir.

Şimşek ve Aktaş (2014), İstanbul'da kamu işletmesi ve kamu üniversitesinde çalışan 185 kişi ile yaptıkları çalışmada, kabullenici ve savunmacı sessizliğin artması yaşam doyumunu azalmakta iken, içedönük kişiliğe sahip olanların kabullenici ve savunmacı sessizlik gösterme, yeniliklere açık olanların ise, ilişkisel sessizlik gösterme eğiliminde ifade edilmektedir. Demirtaş ve Nacar (2018), Elazığg'da 293 okul yöneticisi ve öğretmen ile yaptığ çalışmada, iş doyumu ile örgütsel sessizlik arasında anlamlı bir ilişki tespit edememiştir.

Erol ve Köroğlu (2013)'ün Ankara'da 4 ve 5 yıldızlı otellerde çalışan 221 kişi ile yapılan çalışmasında dönüşümcü liderlik ile örgütsel sessizlik arasında negatif, etkileşimci ve serbestiyetçi liderlik ile örgütsel sessizlik arasında pozitif bir ilişki olduğu sonucu ortaya konulmuştur. Kılıç, Keklik ve Yıldız (2014), kamu, sigorta ve otomotiv sektörlerinde çalışan 242 çalışanla yürüttüğü çalışmada, dönüştürücü liderliğin sergilendiği işletmelerde işgörenlerin sessiz kalmadıkları, etkileşimci ve serbestiyetçi liderliğin sergilendiği işletmelerde işgörenlerin sessiz kaldığını belirlemişlerdir. Dönüşümcü liderlik ile örgütsel sessizlik arasında orta düzeyli ve negatif ilişki tespit eden araştırmalar da bulunmaktadır (Erol, 2012; Taşkıran, 2010; Bildik, 2009). Bu araştırmalar, çalışanların sessiz kalıp kalmama tercihlerinin liderlik tarzıyla yakından ilgili olduğunu göstermektedir. İşletmelerdeki liderlerin 
dönüşümcü liderliği benimsemesi örgütsel sessizliği ortadan kaldırma noktasında önem arz etmektedir.

Kalay, Oğrak, Bal ve Nışancı (2014), kamu üniversitesinde çalışan 240 akademik ve idari personelle yaptıkları araştırmada, personellerin mobbinge maruz kalma düzeyleri ile örgütsel sessizlik tutumları arasında anlamlı bir ilişki tespit ederken, örgütsel sessizlik ile örgütsel sinizm arasında anlamlı bir ilişki tespit edememişlerdir. Çavuş, Develi ve Sarığlu (2015), enerji sektöründe 200 çalışanla yaptıkları araştırmada, mobbing boyutları ile örgütsel sessizlik arasında orta düzeyde anlamlı ve pozitif ilişki saptamışlardır.

Kahya (2015), Atatürk Üniversitesinde 132 akademisyenle yaptı̆̆ı çalışmasında örgütsel sessizlik ile tükenmişlik arasında anlamlı ilişki olduğunu ve örgütsel sessizliğin tükenmişlik üzerinde pozitif etkisini ortaya koymuştur. Aktaş ve Şimşek (2015) tarafından İstanbul'da bir kamu kurumundaki 171 çalışanla yapılan çalışmada, örgütsel sessizlik ile duygusal tükenmişlik ve iş doyumu arasında anlamlı ilişki olduğu ortaya konulmuştur.

Yalçınsoy (2019), Adana ilinde 411 sağlık personeli ile yaptığı araştırmada, örgüt kültürü, örgüt iklimi ve örgütsel sessizlik arasında pozitif yönlü ve zayıf bir ilişki belirlemiştir. Örgüt kültürünün örgütsel sessizlik üzerinde az da olsa etkili olduğunu tespit etmiştir. Acaray ve Akturan (2015), İstanbul merkezli çokuluslu özel bir işletmenin 462 çalışanıyla gerçekleştirilen çalışmada, kabullenici ve savunmacı sessizliğin örgütsel vatandaşlık üzerinde olumsuz etkiye sahipken, prososyal sessizliğin olumlu etkiye sahip olduğu sonucuna ulaşmışlardır.

Önder (2017) Burdur'da 270 çalışanla yaptığı çalışmada, örgütsel sessizlik ile örgütsel bağlılık ve örgütsel adalet arasında orta düzeyli, negatif ve anlamlı bir ilişki saptamıştır. Köse (2014) tarafından Ankara'da dezavantajlı okullarda çalışan 253 öğretmenle yapılan araştırma, örgütsel sessizlik ile örgütsel bağlılık arasında negatif yönlü ve anlamlı ilişki olduğunu ortaya çıkarmaktadır. Salha, Cinnioğlu, Yazıt ve Yenişehirlioğlu (2016) tarafindan Tekirdağ'da yiyecek içecek işletmelerinde çalışan 362 kişi ile yapılan çalışmada, örgütsel sessizlik ile örgütsel bağlılık arasında negatif yönlü ve anlamlı bir ilişki tespit edilmiştir.

Halbaw (2018), Erbil şehrinde 257 öğretmenle yaptığı çalışmada, öğretmenlerin örgütsel adalet algıları ile örgütsel sessizlik arasında düşük düzeyde, anlamlı ve negatif bir ilişki olduğunu tespit etmiştir. Aküzüm (2014) tarafından Diyarbakır'da 357 ilköğretim öğretmeniyle yapılan çalışmada, örgütsel adaletin, örgütsel sessizlik üzerinde önemli bir etkisi olduğu; kabullenici ve korunmacı sessizlik ile negatif ilişkili, korunma amaçlı sessizlik ile pozitif ilişkili olduğu ifade edilmiştir. Güngör ve Potuk (2018), Afyon ilinde 842 öğretmen ile yaptıkları araştırmada, mobbingin örgütsel adalet ve örgütsel sessizlik üzerinde etkili olduğu, örgütsel adalet algısının düşmesinin örgütsel sessizliği artırdığını tespit etmişlerdir. İşleyici (2015) tarafından Zonguldak ilinde 374 öğretmen ve idareci ile yapılan çalışmada, örgütsel sessizlik ile örgütsel adalet arasında orta düzeyli ve anlamlı bir ilişki olduğu, yani 
sessizliğin olduğu okullarda çalışanların örgütsel adalet algıları düşüktür sonucu elde edilmiştir.

\section{Yöntem}

Bu çalışmada, içerik analizi yönteminin bir versiyonu olan tematik içerik analizi (TİA) yöntemi kullanılmıştır. (TİA), inceleme için sağlanan metinlerdeki ortak temaları belirlemek suretiyle görüşme metinlerinin tematik içeriğini gösteren bir analizdir. Nitel araştırmanın ilgi odağı olan bireylerin olayları nasıl deneyimlediği ve anlamlandırdığgnı belirlemeye çalışan bir araştırma yöntemidir.

\section{1.Çalışmanın Deseni}

Günümüzün en yaygın kullanılan nitel araştırma yöntemlerinden biri olan içerik analizi (İA), çok çeşitli alanlarda yapılan bilimsel çalışmalarda yaygın olarak kullanılmaktadır. İçerik analizi yazılı, sözlü veya görsel iletişim mesajlarını analiz etme yöntemidir (Cole, 1988). Krippendorff (2018) ise çalışmasında içerik analizini bilgi, yeni görüşler, gerçeklerin temsili ve eylemler için pratik bir rehber sağlamak amacıyla verilerden bağlamlarına kodlanabilen ve geçerli çıkarımlar yapabilen bir araştırma yöntemi olduğunu ifade etmektedir. İçerik analizi aynı zamanda olayları tanımlamanın ve ölçmenin sistematik olarak objektif bir yoludur (Sandelowski, 1995).

Niteliksel içerik analizi metin verisi içeriği, temaları, kalıpları tanımlamak ve kodlamak için sistematik bir sınıflandırma süreci sonunda, öznel yorumların ortaya konulması için kullanılan bir araştırma yöntemidir (Hseih and Shannon, 2005). Buna rağmen, verileri analiz etmek için sistematik bir kural yoktur; içerik analizinin temel özelliği, metnin birçok kelimesinin çok daha küçük içerik kategorilerine göre sınıflandırılarak analiz edilmesidir. $\mathrm{Bu}$ çalışma da nitel araştırma teknik ve metotları kullanılarak gerçekleştirilmiştir.

İçerik analizinin aşamalarına bakıldığında hem endüktif hem de dedüktif analiz süreçleri üç ana aşama olarak temsil edilir: Bunlar; hazırlık, organizasyon ve raporlama aşamalarıdır. Hazırlık aşaması, analiz biriminin seçilmesi ile başlar. $\mathrm{Bu}$ bir kelime veya tema olabilir. Analiz birimini seçmeden önce neyin ne kadar detaylı analiz edilebileceğine ve örnekleme hususlarına karar verilmesi gerekmektedir. Aynı zamanda seçilen örneklem, evreni temsil etme yeteneğine de sahip olmalıdır (Guthrie vd. 2004).

Nitel içerik analizi süreci, genellikle veri toplamanın ilk aşamalarından başlar. Analiz sürecinde bu aşama, kavram geliştirme ve veri toplama arasında ileri geri hareket etmesini sağlamaktadır (Miles \& Huberman, 1994). Geçerli ve güvenilir çıkarımları desteklemek için nitel içerik analizi, verilerin işlenmesinde bir dizi sistematik ve şeffaf prosedür içermektedir. Tesch (1990) aşamaların bazılarının geleneksel nicel içerik analizi prosedürleriyle örtüşürken, diğerlerinin bu yönteme özgü olduğunu belirtmektedir. Yapılan araştırmaların hedeflerine bağlı olarak, 
içerik analizi daha esnek veya daha standart hale getirilebilmektedir. Ancak genel olarak, verilerin hazırlanması ve bulguların raporlanması suretiyle yapılmaktadır.

$\mathrm{Bu}$ çalışmada literatürdeki sayısız yaklaşım arasından içerik analiz yönteminin bir versiyonu olan TİA yöntemi kullanılmıştır. TİA, nitel verilerin tanımlayıcı bir sunumudur. Nitel veriler, araştırma katılımcılarından toplanan görüşmelerin transkriptleri veya çalışma konusunu yansıtan metinler şeklinde olabilir. TİA, inceleme için sağlanan metinlerdeki ortak temaları belirleyerek görüşme metinlerinin (veya diğer metinlerin) tematik içeriğini göstermektedir. Araştırmacı, katılımcılara araştırma sorusuna yönelik ortak temaların bulunduğu bir soru yöneltir. Katılımcılar, bu soru doğrultusunda, öznel deneyimlerini anlatırlar. Anlatıların ses kayıtları deşifre edildikten sonra metin üzerinden kodlama işlemi yapılır, temalar belirlenir ve bir rapor şeklinde yazılır (Anderson, 2007).

\section{2. İşlem}

Örgütsel sessizliğin, çalışanlar tarafından nasıl deneyimlendiğinin incelenmesi ve yorumlanması amacıyla bu çalışmada TİA yöntemi kullanılmıştır. Örneklem olarak, bir eğitim kurumunda en az 3 yıl ve en çok 10 yıl arasında iş deneyimine sahip 10 kadın seçilerek görüşme yapılmıştır. Nicel araştırmalarda etki büyüklügü ve güç analizi yapıldığından dolayı, aranan en önemli şartlardan biri örneklemin daha geniş olmasıdır. Buna karşın derinlemesine çalışma yürütmeyi amaçlayan niteliksel araştırmalarda; örneklemin büyüklügünden ziyade, örneklemin araştırma sorusuna yönelik uygunluğu aranmaktadır. Başka bir deyişle, en önemli nokta öznel açıklamalara ve yaşantılara ulaşılmasını sağlamaktır (Arkonaç, 2014).

Katılımcılar gönüllü olarak çalışmaya dahil edilmiş ve görüşmeler bire bir yapılarak; örgütsel sessizlik yönünden öznel deneyimlerini anlatmaları istenmiştir. Katılımcılara örgütsel sessizliği anlamaları için kısa tanımlar verilerek, bu tür olayları yaşayıp yaşamadıkları, bu olaylara olan tepkileri ve hisleri sorulmuştur. Örgütsel sessizlik türlerine dair kodlama temalarının çoğu bu soruların cevaplarından çıkarılmıştır. Çalışmada elde edilen veriler, TİA yöntemi kullanarak çözümlenmiştir. TİA sürecinde verilerin kodlanması, temaların oluşturulması, temaların düzenlenmesi, bulguların tanımlanması ve yorumlanması aşamaları izlenmiştir.

\subsection{Verilerin Kodlanması ve Analizi}

Görüşmelerde elde edilen verilerin kodlanması genellikle "endüktif” analiz olarak adlandırılan yöntem ile yapılmaktadır. Endüktif analiz, tümevarım analizi, ana temaların analiz yapanın veri ile etkileşim yolu ile keşfedilmesi olarak bilinmektedir (Patton, 2002). Goetz ve Le Compte (1981) tarafından özetlenen, TİA yönteminin kullanılmasını kolaylaştıran, adımlar takip edilerek veri analizi yapılmıştır. $\mathrm{Bu}$ adımlar, araştırmacılar tarafından ilk olarak ayrı ayrı olarak sonradan ise birlikte yapılmıştır. İlk adım, verilerin gözden geçirilmesi ve ön temaları ve kategorileri belirlemek; ikinci adım, temaların kuramsal alt yapıyla alakalarını belirlemek; üçüncü adım, ortaya çıkan ana kategoriler ve temalar için 
tipolojiler oluşturmak; son adım olarak da ortaya çıkan kategoriler arasında ortaya çıkan ilişkileri değerlendirmektir.

Değerlendirme sonucunda ortaya çıkan ana temalar şu şekilde özetlenebilir. Örgütsel sessizlik genel olarak tanımlanmıştır, kabullenici sessizlik, korumacı sessizlik, koruma amaçlı sessizlik şeklindedir ki, bu temalar örgütsel sessizliğin alt boyutlarına denk gelmektedir. Ayrı olarak, örgütsel sessizliği yordayan, ilişkide olan etmenler de kategori olarak belirlenmiştir. Yordayan faktörler literatürdeki çalışmalar bağlamında mobbing, tükenmişlik, örgütsel adalet, örgütsel bağlılık, liderlik, örgüt kültürü ve örgüt iklimi, örgütsel vatandaşlık vb. konularla ilgili iken; bu araştırmada katılımcılar daha çok mobbing, örgütsel bağlılık ve örgütsel adalet konusunda örgütsel sessizliği deneyimlediklerini ifade etmişlerdir.

\section{Bulgular}

\section{1.Örgütsel Sessizlik}

Örgütsel sessizlik, çalışanların fonksiyonel ve yönetimsel görevlerde ortaya çıkan sorunlarda bilinçli olarak sessiz kalması iken (Premeaux ve Bedeian, 2003:1537), bireyler işle ilgili endişelerini dile getirme konusunda kararsız kalarak, sonunda ceza alabilecekleri korkusuyla bunu yapmaktadır (Milliken ve Morrison, 2003:1563). Çalışanların sessiz kalmayı tercih etmesi ve bunu birlikte hareket etmek suretiyle gerçekleştirmesi işletme için olumsuz sonuçlar doğurabilmektedir (Çakıcı, 2010:3). Bu çalışma örgütsel sessizliğin üç boyutu ve yordayıcı faktörleri üzerine yoğunlaşmıştır.

\subsubsection{Kabullenici sessizlik}

Kabullenici sessizlik, çalışanların, durumu değiştirmek için konuşma, herhangi bir girişimde bulunma veya yardım etmeye istekli olmama durumudur (Ülker ve Kanten, 2009; Ehtiyar ve Yanardağ, 2008). Çalışanların, kendini yetersiz hissetmesi, fikirlerine değer verilmemesinden dolayı hiçbir şeyi değiştiremeyeceği inancının yerleşmesi ve davranışlarını belirlenen kurallara göre şekillendirmesi kabullenici sessizlik olarak tanımlanmaktadır Dyne vd., 2003). Bu araştırmada katılımcılar, kabullenici sessizlik ile ilgili görüşlerini aşağıdaki gibi ifade etmektedirler. İşgörenler bazen bir şeylerin değişmeyeceğine inanıp, konuşsam da fayda etmez düşüncesiyle hareket edebilmektedir. Bu durum işgören tarafından kabullenilmiş bir sessizliği ifade etmektedir.

"Konuşsam da bir şeylerin değişeceğine inanmadığım için, nasıl geldiyse böyle gitsin diye düşündüm”.

"Konuya sabit bir fikir ile bakacaklarından dolayı sessiz kaldım”.

"Tek başıma gücümün yetmeyeceği, tepki versek de sonucun değişmeyeceği gerçeğinin görülmesi sonucunda sessiz kaldım”.

"Sistem sizden güçlü ve hiçbir şekilde değişiklik oluşturamıyorsunuz üstüne üstelik bir de hakkınızı aradı̆̆ını için günah keçisine dönüşüyorsunuz”. 
Yapılan araştırmada katılımcıların verdiği cevaplardan da anlaşıldığı gibi sonucu değiştiremeyeceğine inanan çalışan sessiz kalmayı tercih etmektedir.

\subsubsection{Korunmaci sessizlik}

Korunmacı sessizlik, bir çalışanın ortaya çıkan bir sorun veya durum karşısında düşünce ve fikirlerini açıklaması sonucunda alabilecekleri tepkilerden korktukları için kendilerini koruma amacıyla sessiz kalmaları şeklinde tanımlanmaktadır (Dyne vd., 2003; Acaray, 2015). Çalışanın kendini koruma amacıyla sessiz kalması, yeni fikirlerin ortaya çıkmamasına neden olduğu gibi, sorunların da görülmesine engel olmaktadır (Çakıcı, 2010). Çalışanlar, olaylar karşısında fikir ve görüşleri varken, gelecek tepkilerden korkarak ve içgüdüsel olarak kendini koruma amaçlı olarak sessiz kalmayı tercih etmektedirler. Katılımcılar korunmacı sessizlik bağlamında aşağıdaki gibi kendilerini korumak için sessiz kaldıklarını ifade etmişlerdir.

"İ̧ arkadaşlarımla aramın bozulmasını istemediğimden, arkadaşlarım tarafından istenmeyen biri gibi, yönetici tarafindan çalışmak istemeyen biri gibi görünecektim”.

"Kazanılan hakkın kaybedilmesi, pozisyon ya da unvan değişikliği gibi etmenler işten çıkarılma korkusu yaratarak; birey zorunlu bir kabul ediş gerçekleştirmekte ve kendini koruma amaçl sessizleşmektedir".

"İ̧ hayatına genç yaşta girmiş olmam, yalnız yaşamam ve maddi zorluklar içinde bulunuyor olmam sebebiyle sessiz kalmak zorunda hissediyordum”.

"İşten çıkarmalar gerçekleştiğinde, bu sizin de başınıza gelebilir baskısı oluşturuldu ve bundan dolayı sessiz kaldım”.

Katılımcıların ifadelerinden de anlaşıldığı üzere; iş arkadaşlarıyla aralarının bozulması, kazanılan hakkın kaybı, pozisyon değişikliği, işten çıkarılma vb. korkular nedeniyle görüş veya fikir beyan etmekte sessiz kalmayı tercih etmektedirler.

\subsubsection{Koruma Amaçlı Sessizlik}

Koruma amaçlı sessizlik, çalışanların, konuşması durumunda karışılacakları durumun tersine, konuşmaları durumunda, diğerlerinin veya kurumun zarar göreceği endişesinden dolayı sessiz kalmaları olarak tanımlanmaktadır (Dyne vd., 2003). İşörrenler, kendi çıkarlarından ziyade diğer bireylerin ve örgütün çıkarlarını koruma adına sessiz kalmayı tercih etmektedirler.

Bazen çalışanlar sessiz kalmanın örgüt ve diğer bireylerin menfaatine olduğunu düşünerek sessiz kalmayı tercih etmektedir.

"Önceleri sessiz kalmamayı tercih etmeme rağmen daha sonra birimimdeki arkadaşlarımın da sonuçlardan etkileneceğini düşündüğüm için sessiz kaldım”.

"Sabır, idare ve çaba sarf edip kendi inisiyatifimle çözümler bularak kurumun huzursuz bir ortama dönüşmesini engelledim". 
Katılımcılar arkadaşlarının sonuçtan etkilenmemesi, kurumun huzursuz bir ortama dönüşmemesi adına sessiz kaldıklarını ifade etmişlerdir.

\section{2. Örgütsel Sessizliği Yordayan Etmenler}

Örgütsel sessizlik literatüründe ki araştırmalar genellikle; mobbing, tükenmişlik, örgütsel adalet, örgütsel bağlılık, liderlik, örgüt kültürü ve örgüt iklimi, örgütsel vatandaşlık vb. konularla ilgili yapılmıştır. Bu araştırmada ise, katılımcılar daha çok mobbing, örgütsel bağlılık ve örgütsel adalet konusunda sessiz kaldıklarını ifade etmektedirler.

"Çalışanlar arasında, iş dağılımının hakkaniyetli yapılmaması beni rahatsız etti ".

“Zaman içinde mobbinge maruz kalmış olmamla birlikte sessiz kalmayı seçtim ”.

"Çalışanlar arasında aynı ölçüde kurallara uyma\uymama durumu dengesizlik yaratmaktadır”.

"İ̧sten çıkarılma durumunda bu sizin de başınıza gelebilir baskısı oluşturulduğu için kuruma karşı bağlılı̆̆ım ve sevgim azalmıştır”.

"Yönetime yakın bir takım kişilerin işe geliş gidiş saatlerinin esnek olması, yurtdışı olanaklarından onların daha fazla yararlanıyor olması, ders programlarının daha efektif hazırlanması vb. durumların gerçekleşmesi ".

\section{Tartışma ve Sonuç}

İnsan kaynağı işletmelerin en önemli kaynaklarından biridir ki onların fikir ve görüşleri işletmenin geleceği için önemli bir yer tutmaktadır. İşgörenlerin fikir ve düşüncelerini ifade etmeleri örgütlerde yeni fikirlerin ortaya çıkması açısından önem arz etmektedir. İletişim bir işletmenin başarılı olmasında en önemli unsurlardan biridir. Çalışanlar tarafından sessizliğin tercih edilmemesi için; onların fikirlerini alan, katılımcı ve iyi iletişim kuran bir yönetim, tarzı belirlenmelidir.

Bir eğitim kurumunda çalışan eğitimcilerle yapılan bu araştırma, eğitimcilerin daha çok kabullenici ve korunma amaçlı sessizliği tercih ettiği sonucunu ortaya koymaktadır. Zaman zaman çalışanlar örgütü ve diğer çalışanları korumak için de sessiz kalmaktadırlar.

Örgütsel bağlılık ile örgütsel sessizlik ilişkisini inceleyen çalışmalar; ikisi arasında negatif yönlü bir ilişki olduğunu tespit etmekte ve örgütsel sessizliğin azalması durumunda örgütsel bağlılığın arttığını ifade etmektedirler (Önder, 2017; Karabağ ve Köse, 2014; Salha vd., 2016). Bu çalışmada ise, katılımcılar, örgüte olan bağlılıklarının azalması durumunda sessizliği tercih ettiklerini ifade etmektedirler. Çalışanların sorunlar karşısında ve süreçlerde sessiz kalmamaları onların örgüte olan bağlılıklarını artırıcı yönde etki etmektedir.

Örgütsel adalet ile örgütsel sessizlik ilişkisini inceleyen çalışmalar, örgütsel sessizlik ile örgütsel adalet arasında negatif ve anlamlı ilişki olduğunu tespit etmiştir (Halbaw, 2018; Güngör ve Potuk, 2018; İşleyici, 2015; Aküzüm, 2014). Bu 
araştırmadaki sonuçlar ise, örgütsel adaletsizliği algılayan çalışanların örgütsel sessizliği daha çok tercih ettiğini göstermektedir. Araştırmanın bir diğer sonucu ise, çalışanların mobbinge maruz kalma durumunda daha çok sessiz kaldıkları yönündedir bu durum ise, Çavuş vd., (2015) çalışmasındaki sonuçla benzer niteliktedir.

Örgütsel sessizlik, işletmeleri zor duruma sokacak bir tablo oluşmasına neden olabilecek bir kavramdır. Çalışanlar, kendilerini korumak, örgütü korumak veya durumu kabullenmek suretiyle sessiz kalmaktadirlar. Bu sessizlik durumu uzun vadede örgütleri olumsuz yönde etkilemektedir. Çalışanların örgüte fayda sağlayabilecek bilgileri paylaşmaları özendirilerek sessiz kalmamaları sağlanmaktadır. Diğer araştırmacılara, örgütsel sessizliği yordayan farklı etmenlerle ve farklı sektörlerde çalışanlarla çalışmalar yapmaları önerilebilir.

\section{Kaynakça}

Acaray, A. (2014). Örgüt Kültürü, Örgütsel Sessizlik ve İşten Ayrlma Niyeti Arasındaki Illişkilerin İncelenmesi. Yayınlanmamış Doktora Tezi, Kocaeli Üniversitesi Sosyal Bilimler Enstitüsü, İşletme Ana Bilim Dalı, Kocaeli.

Acaray, A., \& Akturan, A. (2015). The Relationship Between Organizational Citizenship Behaviour And Organizational Silence.Procedia-Social and Behavioral Sciences, 207, 472-482.

Aktaş, H., \& Şimşek, E. (2015). Bireylerin Örgütsel Sessizlik Tutumlarında İş Doyumu ve Duygusal Tükenmişlik Algılarının Rolü. Uluslararası Yönetim Iktisat ve Issletme Dergisi, 11(24), 205-230.

Aküzüm, C. (2014). The Effect of Perceived Organizational Justice on Teachers' Silence: A Practice in Primary Education Institutions. International Journal of Social Sciences \& Education, 5(1), 96-107.

Anderson, R. (2007). Thematic content analysis (TCA): Descriptive Presentation of Qualitative Data. Erişim adresi: http://www.wellknowingconsulting.org/publications/pdfs/ThematicContentAn alysis.pdf

Arkonaç, S. A. (2014). Psikolojide Söz ve Anlam Analizi: Niteliksel Duruş. Ayrıntı Yayınları, İstanbul.

Bildik, B. (2009). Liderlik Tarzları, Örgütsel Sessizlik Ve Örgütsel Bă̆lllık İlişkisi. Gebze Yüksek Teknoloji Enstitüsü, Yüksek Lisans Tezi, Gebze.

Brinsfield, C. T., Edwards, M. S., \& Greenberg, J. (2009). Voice and Silence in Organizations: Historical Review And Current Conceptualizations. Voice and Silence in Organizations, Chapter 1.

Cole F.L. (1988) Content Analysis: Process and Application. Clinical Nurse Specialist 2(1), 53-57. 
Çakıcı, A. (2007). Örgütlerde Sessizlik: Sessizliğin Teorik Temelleri ve Dinamikleri. Çukurova Üniversitesi Sosyal Bilimler Enstitüsü Dergisi, 16(1), 145-162.

Çakıcı, A. (2008). Örgütlerde Sessiz Kalınan Konular Sessizliğin Nedenleri ve Algılanan Sonuçları Üzerine Bir Araştırma. Çukurova Üniversitesi Sosyal Bilimler Enstitüsü Dergisi, 17(1), 117-134.

Çakıc1, A. (2010). Örgütlerde İşgören Sessizliği: Neden Sessiz Kalmayı Tercih Ediyoruz? Detay Yayınc1lık, Ankara.

Çavuş, M. F., Develi, A., \& Sarığlu, G. S. (2015). Mobbing ve Örgütsel Sessizlik: Enerji Sektörü Çalışanları Üzerine Bir Araştırma. İşletme ve İktisat Çalışmaları Dergisi, 3(1), 10-20.

Demirtaş, Z., \& Nacar, D. (2018). Öğretmenlerin İş Doyumu Ve Örgütsel Sessizlik Algıları Arasındaki İlişki. Eğitim Yansımaları, 2(1), 13-23.

Detert, J. R., \& Edmondson, A. C. (2005, August). No Exit, No Voice: The Bind of Risky Voice Opportunities in Organizations. In Academy of Management Proceedings (Vol. 2005, No. 1, pp. O1-O6). Briarcliff Manor, NY 10510: Academy of Management.

Durak, İ. (2014). Örgütsel Sessizliğin Demografik ve Kurumsal Faktörlerle İlişkisi: Öğretim Elemanları Üzerine Bir Araştırma. Atatürk Üniversitesi Iktisadi ve İdari Bilimler Dergisi, 28(2), 89-108.

Dyne, L. V., Ang, S., \& Botero, I. C. (2003). Conceptualizing Employee Silence and Employee Voice as Multidimensional Constructs. Journal of Management Studies, 40(6), 1359-1392.

Ehtiyar, R., \& Yanardağ, M. (2008). Organizational Silence: A Survey on Employees Working in a Chain Hotel. Tourism and Hospitality Management, 14(1), 51-68.

Erol, G. \& Köroğlu, A. (2013). Liderlik Tarzları ve Örgütsel Sessizlik İlişkisi: Otel İşletmelerinde Bir Araştırma. Seyahat ve Otel İşletmeciliği Dergisi, 10(3), 4564.

Erol, G. (2012). Liderlik Tarzları Ve Örgütsel Sessizlik İlişkisi: Otel İşletmelerinde Bir Araştırma. Balıkesir Üniversitesi, Yüksek Lisans Tezi, Balıkesir.

Goetz, J. P., \& LeCompte, M. D. (1981). Ethnographic Research and the Problem of Data Reduction 1. Anthropology \& Education Quarterly, 12(1), 51-70.

Guthrie J., Yongvanich K. \& Ricceri F. (2004) Using Content Analysis as a Research Method to Inquire into Intellectual Capital Reporting. Journal of Intellectual Capital 5 (2), 282-293. 
Güngör, S.K., Potuk, A. (2018). Öğretmenlerin Mobbing, Örgütsel Adalet ve Örgütsel Sessizlik Algıları ve Aralarındaki İlişki. Hacettepe Üniversitesi Ĕgitim Fakültesi Dergisi, 157-164.

Halbaw, A. (2018). Erbil Temel Okullarında Görev Yapan Öğretmenlerin Örgütsel Adalet Algılarıyla Örgütsel Sessizlik Arasındaki İlişki. Doktora Tezi, İstanbul Kültür Üniversitesi, Sosyal Bilimler Enstitüsü, Psikoloji Anabilim Dalı.

Hsieh H.-F. \& Shannon S. (2005) Three Approaches to Qualitative Content Analysis. Qualitative Health Research 15, 1277- 1288.

İşleyici, K. (2015). Örgütsel Adalet ve Örgütsel Sessizlik Arasındaki İlişkinin Incelenmesi (Zonguldak ili örneği). Yayınlanmamış Yüksek Lisans Tezi. Abant İzzet Baysal Üniversitesi Eğitim Bilimleri Enstitüsü. Bolu.

Kahya, C. (2015). Örgütsel Sessizlik ve Tükenmişlik Sendromu İlişkisi. Electronic Turkish Studies, 10(10), 523-546.

Kalay, F., Oğrak, A. Bal, V. \& Nışancı, Z. N. (2012). Mobbing, Örgütsel Sessizlik Ve Örgütsel Sinizm İlişkisi: Örnek Bir Uygulama. Sakarya İktisat Dergisi, 3(2), $1-18$.

Kılıç, R., Keklik, B., \& Yıldız, H. (2014). Dönüştürücü, Etkileşimci ve Tam Serbesti Tanıyan Liderlik Tarzlarının Örgütsel Sessizlik Üzerindeki Etkisini Belirlemeye Yönelik Bir Araştırma. Journal of Management \& Economics, 21(2), 249-268.

Köse, E. K. (2014). Dezavantajlı Okullarda Öğretmenlerin Örgütsel Bağlılıkları İle Örgütsel Sessizlik Arasındaki İlişkiler. Uluslararası Türk Eğitim Bilimleri Dergisi, 2014(2), 28-36.

Krippendorff K. (2018) Content Analysis: An Introduction to its Methodology. Sage Publications, Second Edition, Newbury Park.

Liu, D., Wu, J., \& Ma, J. C. (2009, July). Organizational silence: A survey on employees working in a telecommunication company. In 2009 International Conference on Computers \& Industrial Engineering (pp. 1647-1651). IEEE.

Miles, M, B., \& Huberman, A. M. (1994). Qualitative Data Analysis: An Expanded Sourcebook. (2nd ed). Thousand Oaks, CA: Sage.

Milliken, F. J., \& Morrison, E. W. (2003). Shades of Silence: Emerging Themes and Future Directions for Research on Silence in Organizations. Journal of Management Studies, 40(6), 1563-1568.

Milliken, F. J., Morrison, E. W., \& Hewlin, P. F. (2003). An Exploratory Study Of Employee Silence: Issues That Employees Don't Communicate Upward And Why. Journal Of Management Studies, 40(6), 1453-1476. 
Önder, E. (2017). Ortaöğretim Okullarında Örgütsel Sessizliğin Yordayıcısı Olarak Örgütsel Adalet ve Örgütsel Bağlılık. Journal of Kirsehir Education Faculty, 18(2), 669-686.

Patton, M. Q. (2002). Qualitative Research and Evaluation Methods (3rd edition), Thousand Oaks, Sage.

Pinder, C. C., \& Harlos, K. P. (2001). Employee Silence: Quiescence and Acquiescence as Responses to Perceived Injustice. In Research in personnel and human resources management (pp. 331-369). Emerald Group Publishing Limited.

Premeaux, S. F. (2001). Breaking the Silence: Toward an Understanding of Speaking Up in the Workplace. LSU Historical Dissertations and Theses. 360.

Premeaux, S. F., \& Bedeian, A. G. (2003). Breaking the Silence: The Moderating Effects of Self Monitoring in Predicting Speaking up in The Workplace. Journal of Management Studies, 40(6), 1537-1562.

Salha, H., Cinnioğlu, H., Yazıt, H., \& Yenişehirlioğlu, E. (2016). İşgörenlerin Örgütsel Sessizlik Düzeylerinin Örgütsel Bağl1lıklarına Etkisi: Tekirdağ'daki Yiyecek İçecek İşletmeleri Üzerine Bir Araştırma. Balkan ve Yakın Doğu Sosyal Bilimler Dergisi, 2(3), 5-15.

Sandelowski M. (1995) Qualitative Analysis: What it is and How to Begin? Research in Nursing \& Health 18, 371-375.

Scott, R. L. (1993). Dialectical Tensions of Speaking and Silence, Quarterly Journal of Speech, 79 (1), 1-18.

Şevik, Ü. (2019). Algllanan Örgütsel Politika İle Pozitif Psikolojik Sermayenin İş Tatmini, İşten Ayrllma Niyeti Ve Örgütsel Sessizlik Üzerine Etkisi: Afyonkarahisar Örneği. Sakarya Üniversitesi, İşletme Enstitüsü, Doktora Tezi.

Şimşek, E., \& Aktaş, H. (2014). Örgütsel Sessizlik ile Kişilik ve Yaşam Doyumu Etkileşimi: Kamu Sektöründe Bir Araştırma. Anadolu University Journal of Social Sciences, 14(2), 121-136.

Taşkıran, E. (2010). Liderlik Tarzının Örgütsel Sessizlik Üzerindeki Etkisinde Örgütsel Adaletin Rolü Ve Bir Araştırma. Marmara Üniversitesi, Doktora Tezi, İstanbul.

Tesch, R. (1990). Qualitative Research Analysis Types and Software Tools.. Basingstoke, Hants (UK): Farmer.

Uçar, Z. (2016). İşgören Sessizliği: Teorik Yaklaşımlar Temelinde Betimsel Bir Analiz. Bitlis Eren Üniversitesi İktisadi ve İdari Bilimler Fakültesi Akademik İzdüşüm Dergisi. 1(1), 67-86.

Üçok, D., \& Torun, A. (2015). Örgütsel Sessizliğin Nedenleri Üzerine Nitel Bir Araştırma. İş ve Insan Dergisi, 2(1), 27-37. 
Ülker, F., \& Kanten, P. (2009). Örgütlerde Sessizlik İklimi, İşgören Sessizliği ve Örgütsel Bağlllık İlişkisine Yönelik Bir Araştırma. Aksaray Üniversitesi Íktisadi ve İdari Bilimler Fakültesi Dergisi, 1(2), 111-126.

Yalçınsoy, A. (2016). Örgüt Kültürü ve Örgüt İkliminin Örgütsel Sessizlik Üzerindeki Etkisinin Analizi. Anemon Muş Alparslan Üniversitesi Sosyal Bilimler Dergisi, 7(2), 67-77. 